\title{
Article
}

\section{Medication errors}

\author{
Nuttall, Dilyse
}

Available at http://clok.uclan.ac.uk/23888/

Nuttall, Dilyse ORCID: 0000-0002-0561-5229 (2018) Medication errors. Nurse Prescribing, 16 (8). pp. 364-365. ISSN 2052-2924

It is advisable to refer to the publisher's version if you intend to cite from the work.

10.12968/npre.2018.16.8.364

For more information about UCLan's research in this area go to

http://www.uclan.ac.uk/researchgroups/ and search for < name of research Group>.

For information about Research generally at UCLan please go to http://www.uclan.ac.uk/research/

All outputs in CLoK are protected by Intellectual Property Rights law, including Copyright law. Copyright, IPR and Moral Rights for the works on this site are retained by the individual authors and/or other copyright owners. Terms and conditions for use of this material are defined in the policies page.

\section{CLoK}

Central Lancashire online Knowledge www.clok.uclan.ac.uk 


\section{Calculation Skills: Medication Errors}

The Department of Health \& Social Care (DHSC) (2018), in their Report of the Short Life Working Group on reducing medication-related harm, provided a UK response to the World Health Organisation's (WHO) (2017) Global Patient Safety Challenge, named 'Medication without Harm'. WHO (2017) recognised that there is significant harm caused to patients globally as a result of medicines, resulting in a financial burden of approximately $£ 32$ billion but importantly, a significant proportion of this harm could be avoided.

\section{Question 1}

(i) The total annual drug expenditure in the NHS is approximately $£ 16$ billion, with $56.25 \%$ of that spent in primary care. How much is the annual drug expenditure in primary care?

(ii) The annual drug bill is currently rising by $8 \%$ per annum. Based on a 2018 figure of $£ 16$ billion, what will the annual drug bill be by 2020 ?

\section{Question 2}

Two large scale studies identified prescribing error rates amongst junior doctors, with Foundation Year 1 (FY1) doctors showing a 7.4\% error rate in Ryan, Ross and Davey's (2014) study and an $8.4 \%$ error rate in the study by Dornan, Ashcroft \& Heathfield (2009). Consultant error rates were shown to be $6.3 \%$ (Ryan et al, 2014) and 5.9\% (2009).

Based on the average error rates of the two studies, what is the difference in error rates between an FY1 and a consultant?

\section{Question 3}

A study by Kongkaew, Noyce \& Ashcroft (2008) found that adverse drug reactions (ADRs) accounted for $5.3 \%$ of hospital admissions, with a $10.7 \%$ rate in elderly patients and a $4.1 \%$ rate in children. Answer the following questions on the basis on these figures:

(i) Of the 9,500 children admitted to Hospital A in 2017, how many would be as a result of ADRs? Round your answer up or down to the nearest whole number.

(ii) If 16,300 elderly patients were admitted to Hospital B in 2017 and 1,709 were attributable to ADRs, would this rate be above or below that anticipated?

\section{Question 4}

Another UK strategy identified by the DHSC (2018) to meet WHO (2017) targets, is the use of technology packages such as PINCER which enables identification of patients at risk from hazardous prescribing. DHSC (2018) suggest that trials of PINCER have identified 21,617 cases of hazardous prescribing in a patient population of 2.9 million.

(i) Assuming the same incidence of hazardous prescribing across the UK, how many incidents are likely to be detected if the records of all 255,400 patients in Derby were reviewed? 
(ii) Considering the ADR rates suggested by Kongkaew (2008) in Q3 and the PINCER trial detection rates reported by DHSC (2018), in a population of 7,975 elderly patients admitted to Hospital C, how many of these could have been prevented (assuming that detection of hazardous prescribing prevents ADRs in all cases).

\section{Answers}

\section{Question 1}

(i) $\quad$ 9 billion

(ii) $2019=16$ billion $+8 \%=16+1.28$ billion $=£ 17,000,000,000$

$2020=17.28$ billion $+8 \%=17.28+1.3824=£ 18,662,400,000$

\section{Question 2}

Average FY1 error rate $=(7.4+8.4) \div 2=7.9 \%$

Average consultant error rate $=(6.3+5.9) \div 2=6.1 \%$

Difference $=7.9-6.1=1.8 \%$

\section{Question 3}

(i) $9500 \times 100 \div 4.1=390$ (rounded up)

(ii) $1 \%$ of $16300=163$

$1709 \div 163=10.5 \%$ (rounded up) which is lower than the anticipated $10.7 \%$

\section{Question 4}

$21617 \div 29000000=0.745 \ldots \%$

$0.745 \ldots \%$ of $255400=1904$ (rounded up)

(i) Elderly patients admitted with ADRs $=10.7 \%$ of $7975=853$

$0.75 \%$ of $853=6$ (rounded down)

\section{References}

Department of Health \& Social Care (2018) The Report of the Short Life Working Group on reducing medication-related harm, available online at:

https://www.gov.uk/government/publications/medication-errors-short-life-working-group-report

Dornan T.A.D., Ashcroft D., Heathfield H. et al. (2009) An in depth investigation into causes of prescribing errors by foundation trainees in relation to their medical education. London: General Medical Council.

Kongkaew, C., Noyce, P.R. \& Ashcroft, D.M. (2008) Hospital Admissions Associated with Adverse Drug Reactions: A Systematic Review of Prospective Observational Studies. Annals of

Pharmacotherapy, Vol 42, Issue 7-8, pp. $1017-1025$ 
Royal College of Physicians (2017) Supporting junior doctors in safe prescribing, available online at: https://www.rcplondon.ac.uk/projects/outputs/supporting-junior-doctors-safe-prescribing

Ryan, C., Ross, S. \& Davey P. (2014) Prevalence and causes of prescribing errors: the PRescribing Outcomes for Trainee Doctors Engaged in Clinical Training (PROTECT) study. PLoS One, 9:e79802. 